наукових праць.- Харків, УкрДАЗТ.-2008.№24.-C.75-78.

12. Каличева Н.Є. Організація управління на підприємствах залізничного транспорту в сучасних умовах /
Н.Є. Каличева // Вісник економіки транспорту i промисловості: збірник наукових праць.-Харків, УкрДАЗТ.-2014.№45.-C.167-170.

Стаття надійшла: 19.09.16р.

УДК 338.47:656.2

\title{
ВИРОБНИЧІ ЗАГРОЗИ ЕКОНОМІЧНІЙ БЕЗПЕЦ ПІДПРИЄМСТВ ЗАЛІЗНИЧНОГО ТРАНСПОРТУ
}

\author{
Лапін П.В., здобувач (ДУІТ)
}

У статті обтрунтовується використання показників залізничних транспортних подій, незбереження вантажів, непов'язаних із крадіжками, та показників пожеж у рухомому складі та стаціонарних об'єктах в якості загроз економічній безпеці підприємств залізничного транспорту виробничого характеру. Показано, щзо найбільшу частку економічних збитків для залізнииі серед запропонованих показників становлять пожежі на об'єктах залізничної інфраструктури, що визначає напрямки подальших досліджень та проведення роботи із забезпечення протипожежної безпеки.

Ключові слова: залізничний транспорт, несанкціоноване втручання, транспортна подія, пожежа, загрози економічній безпеці, збитки.

\section{ПРОИЗВОДСТВЕННЫЕ УГРОЗЫ ЭКОНОМИЧЕСКОЙ БЕЗОПАСНОСТИ ПРЕДПРИЯТИЙ ЖЕЛЕЗНОДОРОЖНОГО ТРАНСПОРТА}

\section{Лапин П.В., соискатель (ГУИТ)}

В статье обосновывается использование показателей железнодорожных транспортных происшествий, несохранности грузов, не связанных с кражами, и показателей пожаров в подвижном составе и стационарных объектах в качестве угроз экономической безопасности предприятий железнодорожного транспорта производственного характера. Показано, что наибольшую долю экономического ущерба для железной дороги среди предложенных показателей составляют пожары на объектах железнодорожной инфраструктуры, что определяет направления дальнейших исследований и проведения работ по обеспечению противопожарной безопасности.

Ключевые слова: жселезнодорожный транспорт, несанкционированное вмешательство, транспортное происшествие, пожар, угрозы экономической безопасности, ущерб.

(C) Лапін П.В.

Вісник економіки транспорту і промисловості № 55, 2016 


\title{
PRODUCTION THREATS TO THE ECONOMIC SECURITY OF RAILWAY TRANSPORT ENTERPRISES
}

\author{
Lapin P.V., PhD student (DUIT)
}

In the article among threats to the economic security of the enterprises of railway transport of production character the threats of unauthorized interventions, traffic accidents and fires are selected. It is shown that the largest share of economic losses to the railways of the proposed indicators constitute fire at the facilities of the railway infrastructure, defining directions of further research and work to ensure fire safety.

Keywords: railway, unauthorized intervention, traffic accident, fire, threats to economic security, loss.

Постановка проблеми. Економічна безпека підприємств залізничного транспорту знаходиться під впливом реальних та потенційних загроз інформаційного, науково-технічного, правого, політичного, природного, соціального, фінансового та виробничого характеру [1].

Особливістю виробничої сфери залізничного транспорту $є$ те, що його інфраструктура, рухомий склад, технічний та управлінський персонал розподілені на величезному просторі i залучені до виконання одночасно безлічі технологічних процесів і операцій. Окрім цього, залізниці мають властиві їм особливості, які пов'язані 3 різними природними й географічними умовами, обсягом та структурою навантаження за окремими видами вантажів, їх розподілом за напрямками й у часі, технічною озброєністю та іншими факторами. На деяких регіональних філіях залізниць переважає навантаження (Донецька, Придніпровська), на інших - транзит (Південно-Західна, Південна), робота на прикордонних переходах (Львівська), робота 3 морськими портами (Одеська) [2].

Все це зумовлює уразливість підприємств залізничного транспорту до різних загроз виробничого характеру та важливість роботи, спрямованої на ідентифікацію загроз економічній безпеці виробничого характеру, а отже, і вжиття заходів щодо їх усунення.

Метою cmammi $\epsilon$ визначення та оцінка загроз економічній безпеці підприємств залізничного транспорту виробничого характеру.

Аналіз останніх досліджень $i$ публікацій. Аналіз загроз економічній безпеці підприємств та індикаторів економічної захищеності висвітлено в наукових працях В.В. Белова, О.I. Барановського, В.Л. Дикань, А.В. Козаченко, О.І. Судакової, О І. Христофор та інших. Різні аспекти визначення загроз економічної безпеки підприємств залізничного транспорту розглянуті в роботах Ж.С. Костюка, С.П. Міщенко, Т.О. Муренко, О.Ю. Чередниченко, та інших.

Виділення невирімених частин загальної проблеми. У зв'язку 3 відсутністю єдиної думки щодо вибничих загроз економічній безпеці підприємств залізничного транспорту, не охоплення існуючими підходами усієї повноти цього поняття, а отже, не забезпечення його розкриття повною мірою, питання потребує більш детального розгляду.

\section{Виклад основного матеріалу}

дослідження. Виробничі загрози економічної безпеки підприємств залізничного транспорту, пов'язуються із зниженням рівня безпеки руху, обумовленого недостатнім рівнем надійності рухомого складу; значним

Вісник економіки транспорту і промисловості № 55, 2016 
рівнем зносу матеріально-технічної бази підприємств залізничного транспорту в результаті низьких темпів оновлення його основних фондів; зниженням ефективності організації перевезень, обумовленого низькими темпами впровадження у виробництво досягнень науки і техніки, інформаційних технологій [3].

$$
\text { При ідентифікації }
$$

загроз

економічній безпеці необхідно виявити критичні «больові точки», вихід за межі яких загрожує руйнівними процесами. Отже, з усіх можливих показників загроз економічній безпеці необхідно виділення тих, які відображають ці критичні «больові точки». Саме ці показники використовуються в якості порогових значень загроз економічної безпеки [4].

Вплив на економічну систему підприємства дестабілізуючих факторів характеру викликає його перехід в новий стан. При цьому, підприємство в кінцевому підсумку може перестати існувати (неблагополучний результат) або пройти випробування i повернутися в початковий стан економічної безпеки (благополучний результат).

Опис станів та причиннонаслідкових зв'язків, що виникають в

процесі реалізації загроз економічній безпеці наведений на рис. 1.

Виходячи 3 цих позицій, до виробничих загроз економічної безпеки підприємств залізничного транспорту можна віднести:

1. залізничні транспортні події;

2. незбереження вантажів, непов'язані із крадіжками;

3. пожежі у рухому складі та стаціонарних об'єктах;

Розглянемо першу групу загроз. Залізнична транспортна подія - подія, що трапилася на залізничному транспорті та призвела до загибелі або травмування людей, пошкодження технічних засобів, вантажу, об'єктів залізничного транспорту, дезорганізації руху чи завдала шкоди довкіллю. Транспортні події слід розглядати як реакцію залізничного комплексу на накопичення, розвиток i виникнення негативних тенденцій і явищ при його функціонуванні. Транспортні події - це складні події, які $\epsilon$ завершальними у плетиві несприятливих подій, що мають причинно-наслідкові зв'язки. В залежності від наслідків залізничні транспорті події класифікують як катастрофи, аварії, серйозні інциденти та інциденти [5].

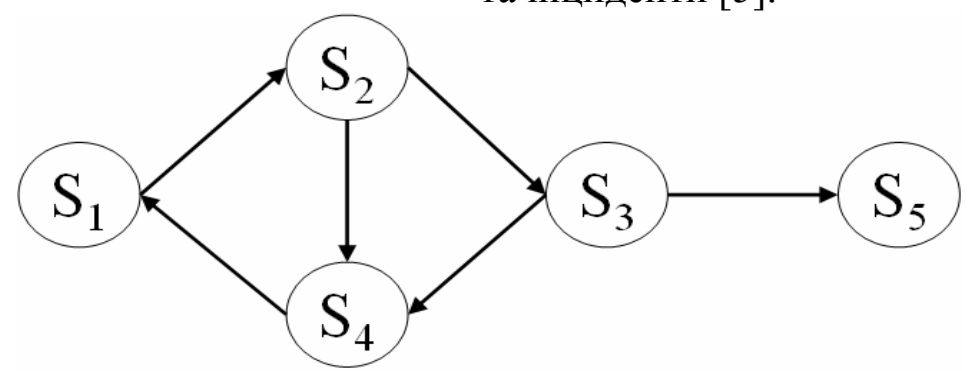

де, S1 - стан безпечного функціонування економічної системи підприємства, перед настанням дії загрози;

S2 - стан реалізації загрози економічній безпеці підприємства;

S3 - стан виконання комплексу завчасних і оперативних заходів, спрямованих на обмеження дії загрози економічній безпеці підприємства;

S4 - стан ліквідації наслідків дії загрози економічній безпеці - проведення комплексу оздоровчих заходів, в т.ч. роботи, спрямованої на відновлення основних фондів, резервів, репутації, навчання персоналу тощо;

S5 - стан, який відповідає припиненню діяльності (поглинання, ліквідація, реорганізація, банкрутство тощо) підприємства внаслідок дії загроз економічній безпеці.

Рис. 1. Граф реалізаиії загроз економічній безпеці підприємства. Джерело: складено автором

Вісник економіки транспорту і промисловості № 55, 2016 
Катастрофа на залізничному транспорті - транспортна подія 3 тяжкими наслідками, що призвела до зіткнення пасажирських або вантажних поїздів 3 іншими поїздами або рухомим складом залізничного транспорту, сходження рухомого складу в пасажирських або вантажних поїздах на перегонах i станціях, унаслідок яких одна або більше осіб загинули чи шість або більше осіб травмовано і (або) пошкоджено рухомий склад залізничного транспорту до ступеня виключення його 3 інвентарного парку в обсязі від трьох одиниць.

Аварія на залізничному транспорті транспортна подія, що призвела до зіткнення пасажирських або вантажних поїздів 3 іншими поїздами або рухомим складом залізничного транспорту, сходження рухомого складу в поїздах на перегонах і станціях, унаслідок яких від однієї до п'яти осіб травмовано і (або) пошкоджено рухомий склад залізничного транспорту до ступеня виключення його 3 інвентарного парку.

Серйозний інцидент на залізничному транспорті- транспортна подія, що виникла під час руху рухомого складу залізничного транспорту, яка могла призвести до аварії та (або) у наслідок якої рухомий склад залізничного транспорту пошкоджено до ступеня капітального ремонту.

До серйозних інцидентів належать:

1. Зіткнення пасажирських або вантажних поїздів з іншими поїздами чи рухомим складом залізничного транспорту, сходження рухомого складу в поїздах на перегонах і станціях, які не належать до аварій за своїми наслідками.

2. Приймання поїзда на зайняту колію, за винятком випадків, передбачених Інструкцією з руху поїздів і маневрової роботи на залізницях України (далі - IРП).

3. Відправлення поїзда на зайнятий перегін, за винятком випадків, передбачених IPП.
4. Приймання і відправлення поїзда за неготовим маршрутом.

5. Проїзд заборонного сигналу, граничного стовпчика або сигнального знака "Межа станції".

6. Вихід рухомого складу залізничного транспорту на маршрут приймання (відправлення) поїзда, на перегін.

7. Відправлення поїзда 3 перекритими кінцевими кранами.

8. Розвалювання вантажу під час руху 3 порушенням встановлених габаритів навантаження.

9. Саморозчеплення, розрив автозчепу або гвинтової стяжки у пасажирському поїзді між вагонами.

10. Переведення стрілки або рухомого осердя хрестовини, що входить до поїзного маршруту перед або під поїздом.

11. Поява на польовому або локомотивному світлофорі (при застосуванні автоматичної локомотивної сигналізації як самостійного засобу сигналізації та зв'язку) дозволяючого показання сигналу замість заборонного або поява більш дозволяючого показання сигналу.

12. Відкриття світлофора за маршрутом, положення стрілок у якому не відповідає цьому маршруту або коли стрілки не мають контролю положення.

13. Відкриття світлофора за маршрутом, що веде до встановленого поїзного маршруту.

Інцидент на залізничному транспорті - транспортна подія, що виникла під час руху рухомого складу залізничного транспорту, але не закінчилася серйозним інцидентом.

До інцидентів належать:

1. Зіткнення чи сходження рухомого складу залізничного транспорту під час виконання маневрів.

2. Переведення стрілки або рухомого осердя хрестовини під маневровим складом. 
3. Саморозчеплення, розрив автозчепу або гвинтової стяжки у вантажному поїзді, між секціями локомотива та між локомотивом і першим вагоном пасажирського поїзда.

4. Розріз стрілки (рухомого осердя хрестовини).

5. Виникнення несправності локомотива, моторвагонного рухомого складу або спеціального рухомого складу, вагонів, несправності колії, пристроїв сигналізації, централізації та блокування, зв'язку, контактної мережі, електропостачання, які призвели до затримки поїзда на перегоні чи станції на дві години i більше понад час, встановлений графіком руху.

6. Падіння деталей рухомого складу поїздів на колію.

7. Злам бокової ферми кузова вантажного вагона, колісної пари або іiі елементів, боковини візка рухомого складу, надресорної чи хребтової балки пасажирських i вантажних вагонів або тріщини балок візків пасажирських вагонів. переводів.

8. Злам рейки і елементів стрілочних за

9. Приймання і відправлення поїзда маршрутом.

10. Зіткнення пасажирських, вантажних поїздів або іншого рухомого складу залізничного транспорту 3 автотранспортними засобами або іншими самохідними машинами на залізничних переїздах через порушення працівниками залізничного транспорту вимог Правил технічної експлуатації залізниць України.

11. Невидача попереджень на поїзди, коли необхідно зменшити швидкість або зупинитися, та (або) у разі неогородження сигналами небезпечного місця для руху поїздів під час виконання робіт.

12. Перехід на інші засоби сигналізації і зв'язку для організації руху поїздів на вісім годин і більше через несправність технічних засобів 3 відліком часу від проходження першого поїзда.

13. Порушення правил розміщення та кріплення вантажу, які не спричинили вихід вантажу за встановлені габарити навантаження, але призвели до затримки поїзда на дві години і більше.

14. Відмова в роботі електричної централізації, ключової залежності стрілок і сигналів на станціях, автоблокування на перегонах, електропостачання на станціях i перегонах, несправності контактної мережі, зв'язку, засобів автоматичного контролю технічного стану рухомого складу під час руху поїздів, що не усунені протягом восьми годин i більше, a пристроїв на залізничних переїздах протягом чотирьох годин i більше 3 відліком часу від проходження першого поїзда.

15. Невірні дії працівників, що призвели до затримки поїзда на одну годину і більше.

16. Несвоєчасне закінчення робіт у "вікно", що призвело до затримки поїздів на дві години і більше.

17. Вихід рухомого складу залізничного транспорту за граничний стовпчик на станції.

18. Наявність у колії гостродефектних рейок (у тому числі в накладках), не замінених протягом восьми годин, крім рейок 3 дефектом 21.2Н.

Стан безпеки руху, пов'язаний із залізничними транспортними подіями, за 2011-2015pp. характеризується даними, наведеними у табл. 1.

Класифікація залізничних транспортних подій по тяжкості наслідків, виражених в натуральних величинах втрат, а саме: кількість об'єктів, які потребують списання та (або) проведення ремонту в необхідному обсязі, числа загиблих і (або) травмованих людей, часу затримок поїздів у вантажному або пасажирському сполученні не відображає тяжкості наслідків, виражених в грошовому еквіваленті. Оскільки кожне 
порушення безпеки руху супроводжується порушенням безпеки руху поїздів (табл. матеріальними втратами, наведемо 2). значення економічних збитків по

Таблиия 1

Динаміка кількості залізничних транспортних подій в структурі ПАТ "Укрзалізниия" у 2011-2015рр.

\begin{tabular}{|c|c|c|c|c|c|}
\hline Вид транспортної події & $2011 \mathrm{p}$. & $2012 \mathrm{p}$. & $2013 \mathrm{p}$. & $2014 \mathrm{p}$. & $2015 \mathrm{p}$. \\
\hline 1 & 2 & 3 & 4 & 5 & 6 \\
\hline Катастрофа & 0 & 0 & 0 & 0 & 0 \\
\hline Аварія & 0 & 1 & 0 & 0 & 0 \\
\hline Серйозний інцидент & 31 & 27 & 20 & 19 & 27 \\
\hline Інцидент & 735 & 736 & 698 & 654 & 575 \\
\hline Всього & 766 & 764 & 718 & 673 & 602 \\
\hline
\end{tabular}

За даними «Аналізу стану безпеки руху в структурі ПАТ «Укрзалізниця».

Таблиия 2

Динаміка збитків ПАТ "Укрзалізниия" від залізничних транспортних подій у 2011 $2015 \mathrm{pp}$.

\begin{tabular}{|c|c|c|c|c|c|}
\hline \multirow{2}{*}{ Найменування категорії } & \multicolumn{5}{|c|}{ Збитки, тис. грн. } \\
\cline { 2 - 6 } & $2011 \mathrm{p}$. & $2012 \mathrm{p}$. & $2013 \mathrm{p}$. & $2014 \mathrm{p}$. & $2015 \mathrm{p}$. \\
\hline 1 & 3 & 4 & 5 & 6 & 7 \\
\hline Залізничні транспортні події & 1412 & 2152 & 2015 & 6025 & 4044 \\
\hline
\end{tabular}

За даними «Аналізу стану безпеки руху в структурі ПАТ «Укрзалізниия».

До другої групи виробничих загроз нами відносено випадки незбереження вантажів непов'язані із крадіжками. Перевезення вантажів залізничним транспортом - це регламентований чинним законодавством порядок і процес вчинення учасниками цього договору необхідних послідовних взаємопов'язаних дій, які були обумовлені у договорі перевезення або транспортній накладній [6].

Неналежне

перевізником договору залізничного перевезення може виражатися у допущені в процесі перевезення або при зберіганні на станційних складах та інших місцях загального користування: розкрадання, недостачі місць і маси, втрати, псування, або пошкодження вантажу. Як викрадення враховують нестачу вантажу, що супроводжується такими обставинами: зривання пломб, закруток, сліди ушкоджень і підробки пломб; проломи у вагоні або контейнері; розкриття тари вантажних місць; викрадення деталей машин на відкритому рухомому складі [7].

Схоронність вантажів залежить від багатьох чинників виробничого процесу. Зокрема, на збереження вантажів насамперед впливає технічна i технологічна оснащеність вагонів, в яких дані вантажі перевозяться. Для забезпечення схоронності вантажу важливо, щоб він був правильно

Вісник економіки транспорту і промисловості № 55, 2016 
закріплений i розташований в вагоні, оснащений необхідною тарою i пломбуванням. Важливу роль відіграє правильний вибір типу вагона для перевезення i порядок складування в ньому вантажу.

Швидкість і терміновість доставки вантажів залежать від потужності локомотива. Більш потужний локомотив забезпечує більш високу швидкість руху і ефективнішу експлуатаційну роботу. Важливим фактором забезпечення терміновості доставки, особливо в сучасних умовах, $є$ розвиненість інфраструктури залізничного транспорту та ступінь іiі заповнення. Розглядаючи вплив інфраструктури на збереження вантажів, що перевозяться, слід відзначити вплив рівня стану верхньої будови колії та якості залізничного рейкового шляху. Поломки, надмірний знос рейок призводять до поштовхів i розгойдування вагонів на шляху прямування, що може вести до втрат вантажу.

Безпека

перевезень

найважливішим показником якості для всіх видів транспорту. На даний показник впливає як технічне і технологічний стан вагонів та локомотивів, так і стан об'єктів інфраструктури. Порушення безпеки утворюються внаслідок несправності парку, недотримання техніки безпеки i правопорядку, порушення роботи передавальних пристроїв і об'єктів інфраструктури. Також на безпеку руху можуть впливати метеорологічні умови (наприклад, скупчення льоду на рейках в холодну погоду може привести до додаткового ковзанню поїзда).

Екологічність транспорту набуває особливого значення i стає найважливішим показником, що характеризує забезпечення процесу перевезень. Стан об'єктів інфраструктури залізничного транспорту частково теж впливає на екологічність. Наприклад, якщо залізничні колії неякісно розташовані або відремонтовані, то це може привести до втрат вантажу в дорозі, а в гіршому випадку - до аварій. Особливу загрозу для екології в даному випадку приносять викиди речовин від небезпечних вантажів в навколишне середовище. Так само, як стан інфраструктури, на екологічність транспорту впливає і стан вагонів. Якщо вагон, підготовлений до перевезення, матиме тріщини і неякісну конструкцію, то деяка частина вантажу, висипаючись 3 вагона на шляху прямування, буде забруднювати смугу відведення i відповідно погіршувати екологію $[8,9]$.

Економічні збитки ПАТ «Укрзалізниця» від незбереження вантажів наведено на рис. 2.

Аналіз гістограми на рис. 2 свідчить, що в середньому в $64 \%$ випадків за останні п'ять років предметом відповідальності за незбереження вантажів є виробничі чинники, непов'язані iз крадіжками. Решта $36 \%$ незбережень вантажів внаслідок крадіжок відноситься до групи соціальних загроз економічній безпеці підприємств залізничного транспорту.

До третьої групи виробничих загроз нами віднесено пожежі у рухому складі та стаціонарних об'єктах підприємств залізничного транспорту.

Відомо, що пожежі можуть привести не тільки до значних матеріальних збитків, але й до виходу 3 ладу рухомого складу, в т.ч. бути причиною зриву виробничих планів, що веде до зниження операційної ефективності і недоотримання прибутку, зриву робочих графіків i додаткових витрат на відновлення об'єктів. Пожежа здатна викликати важкі наслідки, пов'язані 3 отруєнням, опіками та загибеллю людей, адже об'єкти і рухомий склад є місцями великого скупчення пасажирів та персоналу. Небезпечним виглядає і вплив пожеж 3 позиції нанесення екологічних збитків навколишньому середовищу, тому 
що залізниця перевозить значну кількість небезпечних вантажів. Особливу складність викликає те, що в більшості випадків об'єкти залізничної інфраструктури перебувають далеко від територіальних підрозділів пожежної служби державної служби із надзвичайних ситуацій та відомчої пожежної охорони, що не дозволяе надати оперативну та спеціальну допомогу при виникненні пожежі.

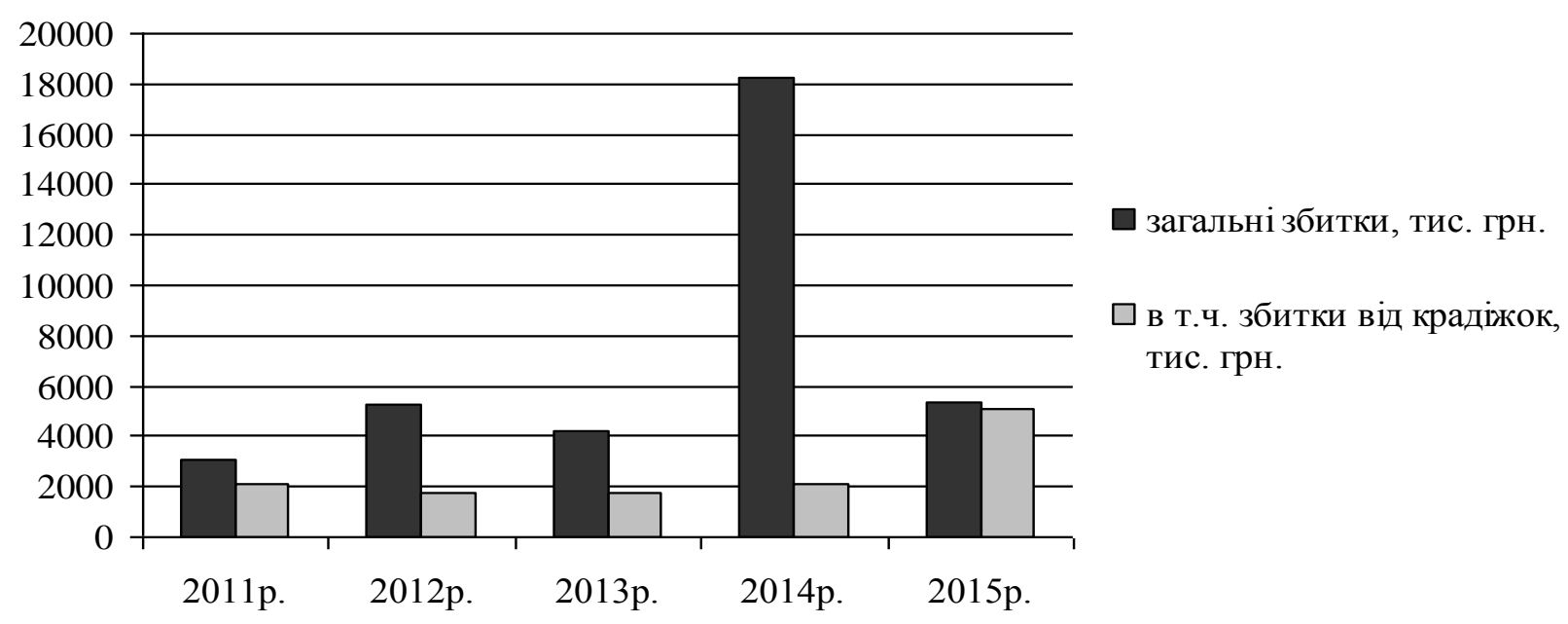

Рис. 2. Динаміка балансових збитків залізниць від незбережених перевезень вантажів за 2011-2015рр. (за даними «Аналізу стану забезпечення збереження майна $i$ матеріальних иуінностей підприємств залізничного транспорту Украӥни»)

Таблиия 3

Динаміка балансових збитків залізниць від залізничних транспортних подій, незбережень вантажів та пожеж на залізничному транспорті.

\begin{tabular}{|c|c|c|c|c|c|c|}
\hline \multirow{2}{*}{ Види загроз } & \multicolumn{6}{|c|}{ Збитки, тис. грн. } \\
\cline { 2 - 7 } & $2011 \mathrm{p}$. & $2012 \mathrm{p}$. & $2013 \mathrm{p}$. & $2014 \mathrm{p}$. & $2015 \mathrm{p}$. & Всього \\
\hline 1 & 2 & 3 & 4 & 5 & 6 & 7 \\
\hline $\begin{array}{c}\text { Залізничні } \\
\text { транспортні події }\end{array}$ & 1412,0 & 2152,0 & 2015,0 & 6025,0 & 4044,0 & 15648,0 \\
\hline $\begin{array}{c}\text { Пожежі у рухому } \\
\text { складі та } \\
\text { стаціонароних } \\
\text { об'єктах }\end{array}$ & 5413,3 & 661,7 & 13244,2 & 4052,4 & 2620,5 & 25992,1 \\
\hline $\begin{array}{c}\text { Незбереження } \\
\text { вантажів, } \\
\begin{array}{c}\text { непов’язані із } \\
\text { кражідками }\end{array}\end{array}$ & 901,0 & 3560,0 & 1265,0 & 16061,0 & 249,0 & 22036,0 \\
\hline
\end{tabular}

За даними «Аналізу стану безпеки руху в структурі ПАТ «Укрзалізниця», «Аналізу стану пожежної безпеки на залізнииях України», «Аналізу стану забезпечення збереження майна і матеріальних иінностей підприємств залізничного транспорту України». 
Макроекономічні наслідки від випадків пожеж у рухомому складі та стаціонарних об'єктах, випадків залізничних транспортних подій та пожеж у рухомому складі та стаціонарних об'єктах наведено у Таблиці 3.

Зазначимо, що за даними Таблиці 3 упродовж 2011-2015pp. загальні збитки від виробничих загроз економічній безпеці підприємств залізничного транспорту склали 63,7 млн. грн. В структурі цих збитків 40\% ( 26 млн. грн.) склали збитки від пожеж у рухому складі та стаціонарних об'єктах, 35\% ( 22 млн. грн.) склали збитки від незбереження вантажів непов'язаних із крадіжками, $25 \%(\sim 15,6$ млн. грн.) склали збитки від залізничних транспортних подій. Першість за критерієм економічних збитків посідають пожежі у рухому складі та стаціонарних об'єктах, а отже пожежна небезпека підприємств галузі залишається серйозною виробничою загрозою економічній безпеці.

Висновки. Запропоновані для індикації виробничих загроз економічній безпеці підприємств залізничного транспорту показники залізничних транспортних подій, незбереження вантажів та пожеж чисельно відображають економічні збитки внаслідок здійснення господарської діяльності залізниць. Очевидно, що ігнорування цих показників перешкоджатиме нормальному розвитку економіки і соціальної сфери та призведе до формування руйнівних тенденцій в царині виробництва послуг із перевезення вантажів та пасажирів.

Метою подальших досліджень в даному напрямку $€$ використання запропонованих показників для розробки прогнозів і програм мінімізації їх впливу на економічну безпеку підприємств залізничного транспорту.

\section{СПИСОК ЛІТЕРАТУРИ}

1. Міщенко С.П. Загрози економічної безпеки підприємств залізничного транспорту в умовах реформування галузі / С.П. Міщенко // Науковий вісник Херсонського державного університету. Серія Економічні науки. - 2014. - Вип.9. Част. 3. - C. 121-125.

2. Економіка залізниці: історія, сьогодення, перспективи розвитку / Г.Д. Ейтутіс, О.М. Кривопішин, І.П. Федорко, В.М. Осовик, М.С. Семенюк; ред.: Г.Д. Ейтутіс, О.М. Кривопішин; Держ. екон.-технол. ун-т трансп., Держ. адмін. залізн. трансп. України, Півд.-Захід. залізниця. - Ніжин: Аспект-Поліграф, 2014. - $291 \mathrm{c}$.

3. Межох 3.П. Проблемы управления экономической безопасностью железнодорожного транспорта: теория, методология, пути решения: автореферат дис. ... доктора экономических наук: 08.00.05 / Моск. гос. ун-т путей сообщ. (МИИТ) МПС РФ. - Москва, 2007. - 48 с.

4. Ворона-Сливинская Л.Г, Проблемы выбора индикаторов экономической безопасности государства и определение их пороговых значений / Л.Г. Ворона-Сливинская, М. В. Лобанов // Проблемы управления рисками в техносфере. 2009. № 4. C. 96-100.

5. Вещева Н. Е. Классификаторы предпосылок и причин железнодорожных транспортных происшествий / H. Е. Вещева, Т. А. Шалаева // Вісник Дніпропетровського національного університету залізничного транспорту імені академіка В. Лазаряна. - 2005. - Вип. 8. - C. 134-167.

6. Сірко Р.Б. Порядок виконання договору перевезення вантажу залізничним транспортом / Р.Б. Сірко // Науковий вісник Херсонського державного університету. - Серія: Юридичні науки. - 2014 . - Вип. 1. - Том 1. - С. 192-196. 
7. Запара В. М. Стан і перспективи забезпечення збереження вантажів при перевезенні залізницями України / В.M. Запара, Я.В. Запара, Н.П. Діжак //Збірник наукових праць Української державної академії залізничного транспорту. - 2014. Вип. 146. - С. 32-37/

8. Соколов Ю.И. Анализ влияния участников перевозочного процесса на обеспечение качества транспортного обслуживания грузовладельцев / Ю.И. Соколов, И.М. Лавров // Этап: Экономическая Теория, Анализ, Практика. - 2012. - № 6 - c. 134-142.

9. Соколов Ю.И. Экономика качества транспортного обслуживания грузовладельцев: монография. М.: УМЦ ЖДТ. 2011. - 184 c.

Стаття надійшла: 3.10.16p.

\title{
УДК 336.22
}

\section{ПОДАТКОВИЙ АНАЛІЗ ЯК СКЛАДОВА ОПТИМІЗАЦЇ̈ ПОДАТКОВОЇ ПОЛІТИКИ ПІДПРИЕМСТВА}

\author{
Лєгостаєва О.О., к.е.н., доцент (ХНУ ім. В.Н. Каразіна) \\ Лисьонкова Н.М., к.е.н., доцент (УкрДУЗТ)
}

Податки - основне джерело формування доходів держави, найважсливіший елемент його економічної політики, Проведення комплексного податкового аналізу дозволяє провести аналіз сукупності податків $i$ зборів, які сплачуються конкретним підприємством у різні роки, виявити найбільш значущі фактори, щзо викликали зміни в динаміці $і$ структурі податкової сукупності, а також сформувати інформаџійну податкову базу підприємства, щзо дозволить забезпечити функиіонування ефективної $i$ оптимальної системи податкової політики підприємства.

Ключові слова: податкова система, податкова політика, оптимізація оподаткування, податкове навантаження, податковий аналіз

\section{НАЛОГОВЫЙ АНАЛИЗ, КАК СОСТАВЛЯЮЩАЯ ОПТИМИЗАЦИИ НАЛОГОВОЙ ПОЛИТИКИ ПРЕДПРИЯТИЯ}

\author{
Легостаева Е.А., К.э.н, доцент (ХНУ им. В.Н.Каразина) \\ Льсенкова Н.Н. к.э.н, доцент (УкрГУЖТ)
}

Налоги - основной источник формирования доходов государства, важнейший элемент его экономической политики. Проведение комплексного налогового анализа позволяет провести анализ совокупности налогов и сборов, уплачиваемых конкретным предприятием в разные годы, выявить наиболее значимые факторы, вызвавшие изменения в динамике $u$ структуре налоговой совокупности, а также сформировать информационную налоговую базу предприятия, что позволит обеспечить функционирование эффективной $и$ оптимальной системы налоговой политики предприятия.

Ключевые слова: налоговая система, налоговая политика, оптимизация налогообложеня, налоговая нагрузка, налоговый анализ.

(С Лєгостаєва O.O., Лисьонкова Н.M.
Вісник економіки транспорту і промисловості № 55, 2016 